\title{
Some water mites (Acari, Parasitengona) from the island of Minorca
}

\author{
Antonio García-Valdecasas; Javier García Avilés
}

Museo Nacional Ciencias Naturales. c/Castellana, 80. Madrid, 6

\author{
RESUMEN \\ ALGUNAS HIDRACNELAS (ACARI, PARASITENGONA) DE LA ISLA DE \\ MENORCA.
}

Las hidracnelas de las islas Baleares son prácticamente desconocidas, contabilizándose un total de 9 especies entre Mallorca e Ibiza. Muestras tomadas en la isla de Menorca han rendido un total de 10 especies, con lo que el número total en el conjunto de las islas se eleva a 16 .

Entre las especies encontradas cabe mencionar Oxus strigatus (Mull.) y Aturus protzi Piersig, ambas considerad as como muy raras.

Aunque puede resultar prematuro, todos los indicios apuntan a una mayor afinidad faunística (al menos en lo que a hidracnelas se refiere) entre las islas Baleares y la Península Ibérica, reforzando el criterio de inclusión de las mismas en la subregión 1 de Limnofauna Europaea.

\section{INTRODUCTION}

Only two previous works have dealt with the water mite fauna of the Balearic islands. VIETS (1955) examined a small sample from Mallorca and Ibiza, and LUNDBLAD (1972) one from Mallorca (table I). A total of nine species and subspecies with only two taxa restricted to the islands was recorded. In this work we present the results of samples taken on the island of Minorca to which there is only a reference to "Hydraca" rina" by MARGALEF (1952). Ten species were found and the number of water mites known to the islands raised to sixteen. Continued sampling will no doubt reveal a richer fauna than is currentlly known.

\section{SAMPLING SITE AND METHODS}

All the samples were taken at the end of 1979 and the beginning of 1980. A brief description of the sampling sites follows:

Ricra de San Juan. A canalised stream 5 $\mathrm{m}$ wide. At the time of sampling the water 
flow was $2.0 \mathrm{~m}$ wide and $0.5 \mathrm{~m}$ deep. Mud bottom with some plant detritus. $10 \mathrm{~m}$ above sea level. The stream flowed through cultivated land. (1-11-79): Lebertia sp. Stream of Santa Galdana. $2 \mathrm{~m}$ wide and 0.2 $\mathrm{m}$ deep. Bottom of calcareous stones and with few water plants. $20 \mathrm{~m}$ a.s. 1. (25-9-79) slightly flowing water: Hydrodroma despiciens torrenticola, Oxus strigatus, Limnesia fulgida, Hygrobates longipalpis. Neumania uncinata.

(20-1-80) medium flowing water: Sperchon papillosus compactilis, Torrenticola sp. Neumania uncinata, Aturus protzi, Kongsbergia largaiolli.

Samples were taken with a conical net of 180 micras and then fixed in Angelier's fluid (ANGELIER, 1953). After washing in the laboratory through two metal sieves of 1 $\mathrm{mm}$ and $0.250 \mathrm{~mm}$ mesh, the last fraction was sorted and the mites stored in Koenike's fluid.

\section{RESULTS}

Hydrodroma despiciens torrenticola (WALTER, 1908).

Only one male was in the samples. The morphology of this subspecies and the nominate species is very similar. The main differences concern the habitat and chaetotaxy of the three posterior pairs of legs: $H$. despiciens s. s. lives mainly in lentic waters and $H$. despiciens torrenticola in streams. LUNDBLAD (1962) gives a revision of the literature concerning this species. The chaetotaxy of our specimen clearly falls within the variability given by LUNDBLAD for torrenticola swimming hairs: II-L-5 (h): 0; III-L-4 (v): 0; III-L-4 (h): 7, III-L-5 (v): 0; III-L-5 (h): 4; IV-L-4 (v): 7; IV-L-4 (h). 7; IV-L-5 (v): 5; IV-L-5 (h). 4.

VIETS (1955) found $H$. despiciens s.s. in a small stream on Ibiza. $H$. despiciens i. mrenticola is widely distributed in Europe.

Sperchon papillosus compactilis KOENIKE; 1911.

LUNDBLAD (1956) considered $S$. compactilis KOEN, as a subspecies of $S$. papillo- sus THOR, the diagnostic difference being the lack of ventral setae on P.III. This subspecies is found in central Europe, Iberian Peninsula and north Africa.

\section{Lebertia sp.}

Both VIETS and LUNDBLAD found Lebertia (Pilo.) porosa (THOR) on the island of Mallorca. Our female specimen does not belong to this species, but we have been unable to identify it. Further sampling should make its identification feasible.

Oxus strigatus (MÜLL.) $[=0$. oralis? (MÜLL.)].

Only one female of this rare species:

Ventral body length: 801 " microns. Length between anterior end of first coxa and posterior end of fourth: 684 microns. Genital field: 144 microns in length, 95 microns maximum width.

Dorsal length of palp segments: P-1: 33 microns; P-II: 50 microns; P-III: 38 microns; P-IV 66 microns; P-V: 25 microns. Chelicera: 142 microns long.

Dorsal length of first and fourth leg segments: I-L-2: 45 microns; I-L-3: 63 microns; I-L-4: 90 microns; I-L-5: 104 microns; I-L-6: 95 microns; IV-L-1: 77 microns; IV-L-2: 54 microns; IV-L-3: 90 microns; IV-L-4: 127 microns; IV-L-5: 172 microns; IV-L-6: 176 microns. (fig. 1).

This species has been found in scaterred parts of Europe (VIETS, 1978).

\section{Torrenticola sp.}

VIETS (1955) described Torrenticola pharyngealis aberrans from a male found on Mallorca. We hoped that our female specimen could be of the same. subspecies but detailed comparisons revealed that it is another species. It belongs to the T. elliptica gruppe, but with only one specimen we do not feel sure enough of its identity. As with the specimen of Lebertia, further sampling should make easier its identification.

Limnesia fulgida $\mathrm{KOCH}, 1836$

A taxon widely distributed throughout Europe up to north America. 


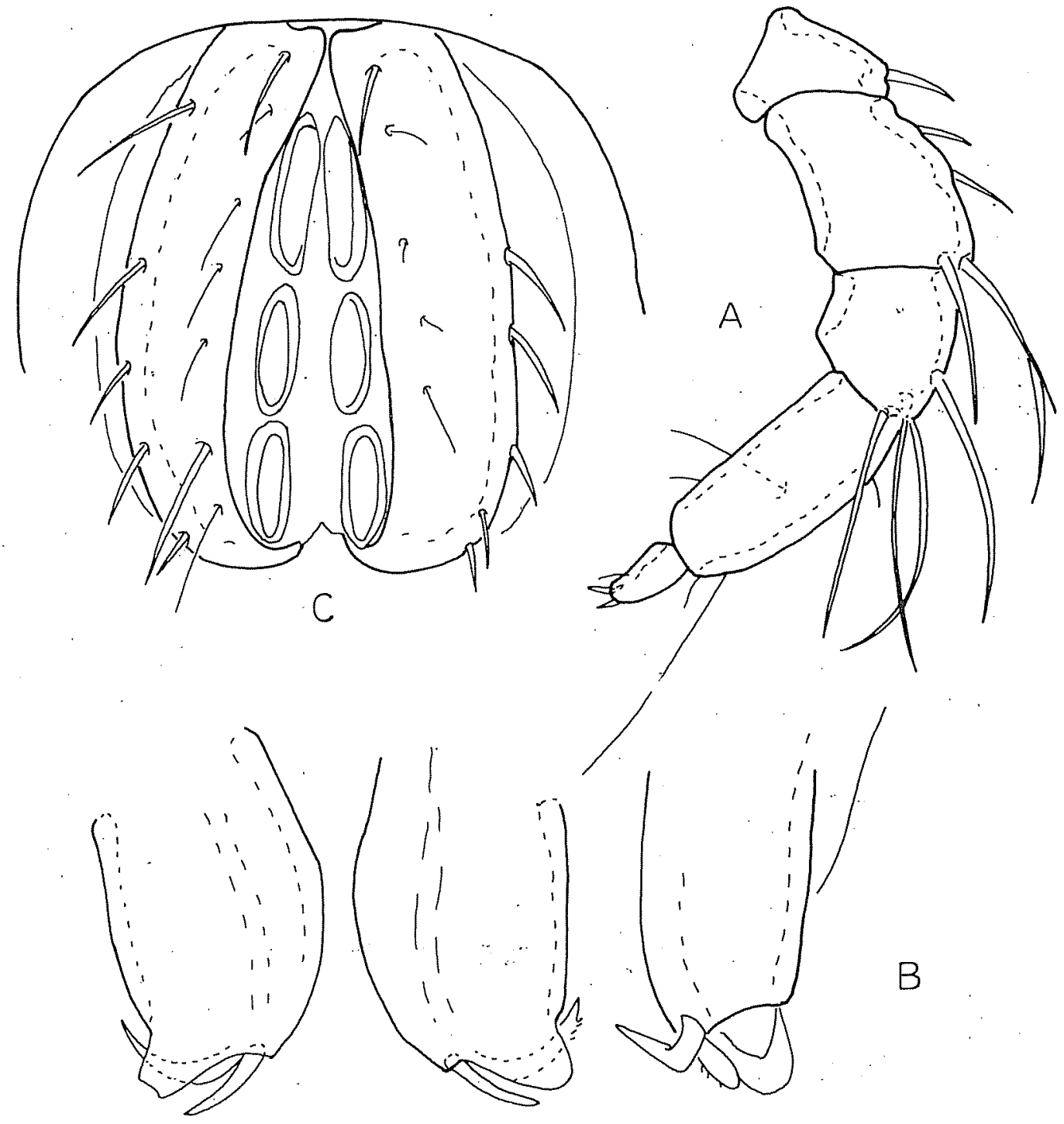

Fig. 1. Oxus strigatus A) Palp (Palpo). B) Anterior end of first coxa (Extremo anterior de la primera coxa) C) Genital field (Area genital).

Hygrobates longipalpis (HERMANN, Atums protzi PIERSIG, 1901 1804)

Previously found in the island of Ibiza. Holartic distribution.

This species is considered to be very rare. Male: Ventral length to anterior end of first coxa: 380 microns. Width between insertions of fourth legs: 255 microns.

Dorsal length of palp segments: P-I: 24

Neumania uncinata WALTER, 1927

Known from scattered places in southern Europe. microns; P-II: 59 microns; P-III: 36 microns; P-IV: 84 microns; P.V: 34 microns.

Posterior pair of legs... with a complex. 


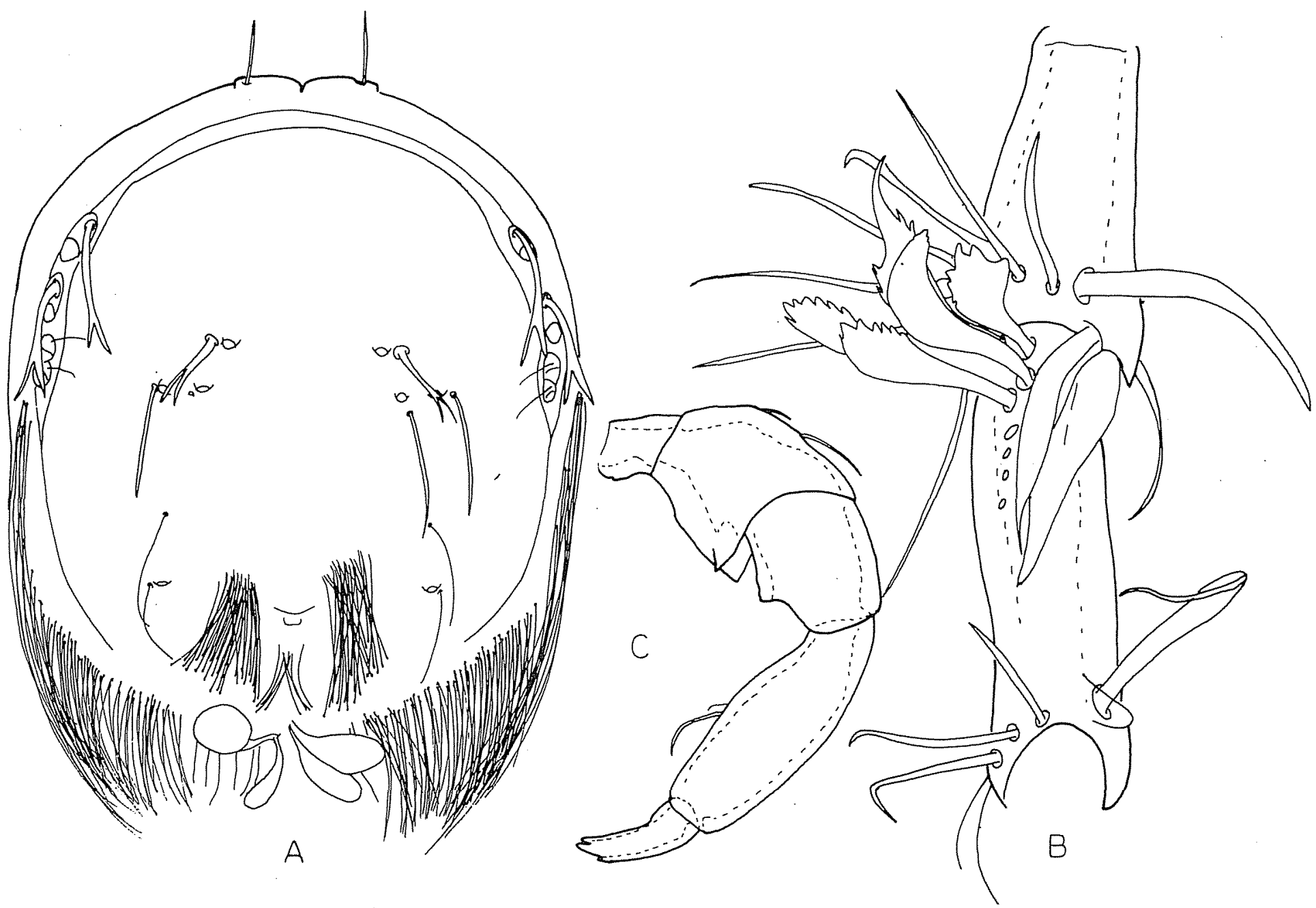
Fig. 2. Aturus protzi A) Dorsal view (Superficie dorsal). B) Four and fifth segments of last pair of legs (Cuarto y quinto segmentos del último par de patas).
C) Palp (Palpo). 
chaetotaxy on fourth and fifth segments (fig. 2).

This species has been found in Germany, Pyrénées, Sierra de Guadarrama (Spain) and Corsica.

Kongsbergia largaiolli (MAGLIO, 1909)

Species found in Britain, central and south Europe.

\section{FINAL REMARKS}

Table I summarizes our present knowledge of the water mite fauna of the Balearic islands. Only two taxa, Torrenticola pharyngealis aberrans and Eylais comptesarti seems to be restricted to the islands. As a whole, the water mite fauna has more similarities with the Iberian Peninsula than with Corsica or region 3 of Limnofauna Europaea (ILLIES, 1978 ) and support the inclusion of these islands in region 1.

Finally we would like to point out a striking fact: almost all the taxa in every sampling date belongs to a different water mite family. It could be said that the taxonomic dispersion tends here to a maximun.

\section{ACKNOWLEDGEMENTS}

We are very grateful tọ T. GLEDHILL. K.O. VIETS and E. ORTIZ for helpful advice.
TABLE I. Water mites from Balearic islands. (Hidracnelas de las Islas Baleares). 1955 (VIETS 1955), 1972 (LUNDBLAD 1972), 1981 (This work).

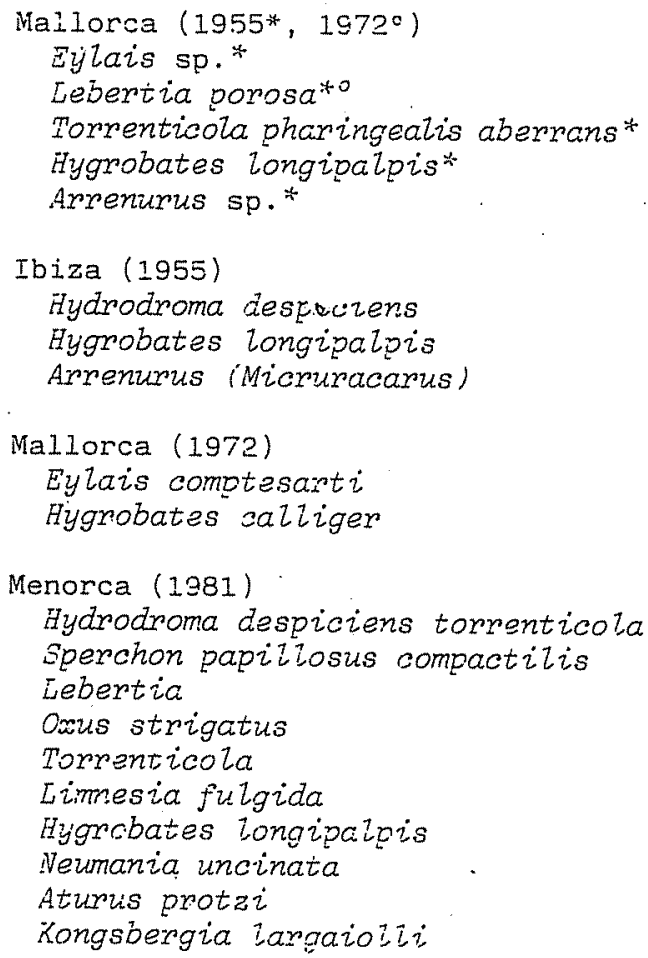

ANGELIER, E. 1953. Recherches écologiques et biogéographiques sur la faune des sables submergés. Arch, Zool. expé. gén., Paris 90:37161.

ILLIES, J. 1967, 1978. Limnofauna Europacea. G. Fischer, Stuttgart, New York.

LUNDBLAD, O. 1956. Zur Kenntnis süd-und mitteleuropäischer Hydrachnellen. Ark. Zool. 10: 1-306.

-1962. Di Hydracarinen Schwedens. II. Ark. Zool. 14: 1-635.
LUNDBLAD, O. 1972. Einige Wassermilben aus Mallorca, Gomera und Kamerun. Ent. Ts. Arg., 93: 113-122.

MARGALEF, R. 1952. Materiales para la hidrobiología de la isla de Menorca. P. Inst. Biol. Apl., 11: 5-112.

VIETS, K. 1955. Kleine Sammlungen europäischer und aussereuropäischer Wassermilben (Hydrachnellae, Acari). Abh.' Nat. Ver. Bremen. 34: 1-26.

VIETS, K.O.. 1978. Hydracarina. En Limnofauna Europea (J. ILLIES ed.) : 154-181. G. Fischer. Stuttgart, New York. 